\title{
PENGARUH ENTREPRENEURIAL ORIENTATIONTERHADAP FINANCIAL PERFORMANCE DENGANMARKETING CAPABILITY DAN ORGANIZATIONAL LEARNING SEBAGAI VARIABEL INTERVENING PADA PT.ASURANSI CENTRAL ASIA DI SURABAYA
}

\author{
Anthony Wijaya ${ }^{1}$ dan Diah Dharmayanti ${ }^{{ }^{*}}$ \\ Jurusan Manajemen Pemasaran, Universitas Kristen Petra Surabaya \\ Email: anhonywijaya01@gmail.com; dharmayanti@peter.petra.ac.id \\ * Korespondensi
}

\begin{abstract}
Abstrak: Penelitian ini bertujuan untuk menganalisis pengaruh Orientasi Kewirausahaan (pengambilan resiko, proaktif, inovasi, persaingan agresif, otonomi), terhadap Kinerja Keuangan di PT Asuransi Central Asia di Surabaya, dengan Kemampuan Pemasaran (pemasaran sensasional, Pemasaran Kemampuan, Pemasaran Target dan Positioning), dan Pembelajaran Organisasi (Komitmen untuk belajar, Bebasgi Visi, Intra-organisasi Pembangian pengetahuan, pemikiran terbuka) sebagai variabel intervening. Penelitian ini dilakukan dengan menyebarkan kuesioner kepada 100 responden klien cabang PT.Asuransi Centra Asia Surabaya. Teknik analisis yang digunakan adalah teknik analisis kuantitatif dengan metode path analysis
\end{abstract}

Kata kunci: Orientasi kewirausahaan, pemasaran kemampuan, organizatiional learning, kinerja keuangan

\begin{abstract}
This study has the objective to analyze the effect of Entrepreneurial Orientation (Risk-taking, pro-activeness, innovativeness, competitive agresiveness, autonomy), to the Financial Performance at PT Asuransi Central Asia in Surabaya, with Marketing Capability (Marketing Sensing Capability, Marketing Learning Capability, Marketing Targeting and Positioning), and the Learning Organization (Commitment to Learning, Shared Vision, Intra-organizational Knowledge Sharing, Open Mindedness) as an intervening variable. This research was conducted by distributing questionnaires to 100 respondents client of PT. Asuransi Centra Asia Surabaya branch. Analysis technique used is quantitative analysis techniques with methods of path analysis.
\end{abstract}

Keywords: Entrepreneurial Orientation, Marketing Capability, Organizatiional Learning, Financial Performance.

\section{PENDAHULUAN}

Berdasarkan data yang di himpun oleh majalah Media Asuransi edisi 298, menyatakan bahwa perlambatan ekonomi yang tak berujung membuat Bank Indonesia (BI) terus mengurangi target pertumbuhan ekonomi pada tahun 2015 dari semula 5-5.2 persen menjadi 4.7-5.1 persen. Menurut Gubernur BI Agus Martowardjojo, revisi dilaksanakan karena mengingat adanya perlambatan ekonomi yang disebabkan oleh lambatnya investasi swasta dan pemerintah. Hal ini terjadi lantaran penyerapan anggaran yang dilakukan pemerintah tidak sesuai harapan.

Perilaku wait and see investor swasta juga menyebabkan pelemahan investasi, sehingga jika terjadi perbaikan kondisi perekonomian, maka itu akan mulai terjadi pada kuartal tiga 2015, dan terus berlanjut ke kuartal empat 2015. Kenaikan ini didukung karena adanya peningkatan belanja pemerintah dengan projek infrastruktur. Hal ini diharapkan terus berlanjut hingga tahun 2016.

Kondisi ini ekonomi dunia yang melambat mengakibatkan lesunya perkonomian Indonesia.
Kondisi ekonomi Indonesia yang lesu, mengakibatkan konsumsi masyarakat mengalami penurunan, yang terbukti dengan banyaknya kebutuhan pokok yang harganya anjlok. Deputi Statistik Distribusi dan Jasa Badan Pusat Statistik (BPS), Sasmito Hadi Wibowo mengungkapkan, penurunan ini sudah terjadi sejak 2 pekan pertama September 2015.

Dengan adanya konsumsi yang menurun di segala aspek tentunya akan menurukan pertumbuhan di berbagai industri yang ada di Indonesia, baik industri produk maupun jasa.

Penurunan ini juga dirasakan pada industri asuransi di Indonesia. Pertumbuhan di bidang asuransi yang biasanya rata-rata 14 persen sekarang menjadi paling bagus 10 persen, bahkan banyak asuransiasuransi yang tidak bertumbuh atau minus pertumbuhannya, bahkan ada asuransi yang gulung tikar karena perlambatan ekonomi ini (Media Asuransi, edisi 298 : 18).

Dalam perusahaan pola pikir kewirausahaan akan menciptakan orientasi kewirausahaan atau entrepreneurial orientation. Secara singkat entrepreneurial orientation adalah suatu strategi perusahaan yang 
memiliki kecenderungan untuk bertindak inovatif, proaktif, dan mengambil resiko. Entrepreneurial orientation awalnya melibatkan proses pembuatan strategi dan mewakili kebijakan dan praktik yang membentuk dasar bagi tindakan dan keputusan dalam berwirausaha (Rauch, Wiklund, Lumpkin \& Frese, 2009: 763). Covin dan Slevin (1989: 76) menyatakan bahwa tingkatan/level yang diterapkan entrepreneurial orientation dalam bisnis sering ditunjukkan oleh sejauh mana pengusaha dan manajer bersedia mengambil risiko untuk mendukung perubahan dan inovasi untuk akhirnya mendapatkan keunggulan kompetitif.

Dengan adanya berbagai fenomena ekonomi mulai dari ekonomi dunia hingga berpengaruh pada ekonomi nasional tentunya PT. ACA harus terus mengembangkan entrepreneurial mindset yang ada dalam perusahaan, serta terus mengembangkan kemampuan pemasarannya supaya dapat terus menjawab kebutuhan pasar, dan tidak lupa untuk terus menyesuaikan diri dengan lingkungan ekonomi yang ada melalui Organizational Learning, sehingga perusahaan dapat terus bertumbuh dari waktu ke waktu.

Berdasarkan latar belakang diatas, penulis ingin melakukan penelitian mengenai pengaruh Entrepreneurial Orientation terhadap Financial Performance melalui Marketing Capabilities dan Organizational Learning pada PT. Asuransi Central Asia di Surabaya.

\section{Tujuan Penelitian}

Tujuan penelitian adalah untuk mengetahui pengaruh Entrepreneurial Orientation terhadap Financial Performance dengan Marketing Capability dan Organizational Learning pada PT. ACA di Surabaya.

\section{URAIAN PENELITIAN}

\section{Entrepreneurial Orientation}

Entrepreneurial Orientation didefinisikan sebagai orientasi kewirausahaan awalnya melibatkan proses pembuatan strategi-dan mewakili kebijakan dan praktik yang membentuk dasar bagi tindakan dan keputusan dalam berwirausaha (Rauch, Wiklund, Lumpkin \& Frese, 2009: 763). Entrepreneurial Orientation membantu perusahaan melihat adanya perkembangan pasar yang terus maju pesat, serta meningkatkan kepekaan perusahaan terhadap kebutuhan pasar/masyarakat. Kemudian entrepreneurial orientation membantu perusahaan untuk melakukan inovasi-inovasi produk, serta mampu dan berani mengambil keputusan.
Lumpkin dan Dess (1996) menetapkan lima dimensi orientasi kewirausahaan. Tiga dimensi pertama awalnya dikembangkan oleh Miller pada tahun 1983 dan model selanjutnya kemudian diperpanjang oleh Lumpkin and Dess (1996). Lima dimensi entreprenurial orientation adalah variabel independen yang membantu keberhasilan usaha sebagai variabel dependen. Lima dimensi tersebut yang dikenal sebagai berikut:

a) inovasi,

b) pengambilan risiko,

c) pro-aktif,

d) otonomi,

e) dan agresivitas kompetitif.

\section{Marketing Capability}

Day (1994) mengatakan bahwa Marketing Capability merupakan suatu proses yang dirancang untuk merancang pengetahuan integratif yang kolektif, keterampilan, dan sumber daya dari perusahaan ke pasar terkait kebutuhan bisnis, yang memungkinkan bisnis untuk menambah nilai barang dan jasa, serta memenuhi tuntutan kompetitif. Dengan adanya marketing capability perusahaan bisa merasakan dan merespon perubahan yang terjadi di pasar seperti kemajuan atau perkembangan pesaing, perkembangan teknologi, sehingga perusahaan dapat memanfaatkan kemampuan dan sumber daya dari partner untuk menghasilkan nilai-nilai serta memfasilitasi perusahaan untuk mengetahui kebutuhan customer.

Hal ini dapat membantu perusahaan untuk mengembangkan produk-produk baru atau memperbaharui produk yang sudah ada dengan spesifikasi dan atribut baru untuk mampu menghadapi persaingan. Untuk memenangkan persaingan yang begitu ketat di pasar, tentunya perusahaan harus memberikan respon yang cepat dan inovasi produk yang fleksibel, serta dikombinasikan dengan kemampuan sektor marketing yang handal dan unggul dalam perusahaan, sehingga inovasi dapat menjadi upaya perusahaan untuk mengembangkan marketing capability perusahaan. Dimensi Marketing Capability (Sarutaya Sukdej Phaprukbaramee Ussahawanitchakit, 2015):

a) Marketing Sensing Capability,

b) Marketing Learning Capability,

c) Marketing Targeting and Positioning,

\section{Organizational Learning}

Organization learning merupakan organisasi yang bergerak dengan sistem terbuka tidak memiliki 
pikiran fisiologis sebagai individu, tetapi organisasi memiliki sistem kognitif dan memori. Meskipun anggota organisasi seringkali masuk dan keluar, organisasi yang konstan dengan norma-norma, nilainilai, dan kebijakan yang sudah ada tanpa harus membangun kembali. Oleh karena itu, belajar dalam sebuah organisasi hasil dari akumulasi pembelajaran individual (Calantone et al, 2002:. 517). Lopez, Peon dan Ordas (2005, p.228) menjelaskan Orgnizational Learning sebagai suatu proses dinamis dari penciptaan, mendapatkan dan asimilasi pengetahuan untuk mengembangkan sumber daya/kemampuan yang berkontribusi terhadap efektivitas organisasi yang lebih tinggi dan kinerja yang lebih baik. Dari perspektif manajemen, Organizational Learning adalah perubahan pengetahuan masyarakat, kognisi dan perilaku yang terkait erat dengan perubahan organisasi lainnya (Argote, 2011).

Dimensi Organizational Learning menurut Crossan, Lune and White (1999) adalah intuiting, integrating, inteprating, dan institutionalizing. Sedangkan Organization Learning menurut Calantone et al, 2002 mengemukakan bahwa di dalam organization learning yang efektif diperlukan 4 dimensi yang akan memungkinkan organisasi untuk belajar, berkembang, dan berinovasi yakni:

a) Commitment to Learning,

b) Shared Vision,

c) Intra-organizational Knowledge Sharing,

d) Open Mindedness.

\section{Financial Performance}

Financial Performance dapat didefinisikan sebagai pencapaian tujuan organisasi yang terkait dengan profitabilitas dan pertumbuhan penjualan dan pasar saham, serta pemenuhan umum tujuan strategis perusahaan (Hult, Hurley dan Knight, 2004: 430431). Informasi keuangan merupakan data yang paling sensitif bagi perusahaan sehingga banyak perusahaan yang menolak memberikan informasi yang berisi indikator seperti profitabilitas dan ROI (Lopez, Peon, dan Ordas, 2005). Analisis perusahaan manufaktur yang terdaftar menunjukkan bahwa rasio ekuitas Dept adalah positif dan sangat terkait dengan semua rasio profitabilitas, seperti: Gross Profit, Operating Profit dan Net Profit Ratios (B.Nimalathasan \& Valeriu Brabete 2010).

Dimensi yang digunakan (Puwanenthiren Pratheepkanth, 2011):
a) Gross Profit,
b) Net Profit,
c) Return on Investment,

d) Return on Asset,

e) dan Return on Equity.

\section{Kerangka Berpikir}

\begin{tabular}{|c|c|}
\hline & $\begin{array}{l}\qquad \text { LATAR BELAKANG } \\
\text { Adanya fenomena perlambatan ekonomi global } \\
\text { Melemahnya nilai rupiah terhadap dolar AS } \\
\text { Fenomena tersebut mempengaruhi pertumbuhan industri asuransi kerugian } \\
\text { PT. Asuransi Central Asia memiliki orientasi kewirausahaan dalam menghadapi } \\
\text { fenomena yang ada } \\
\text { Pertumbuhan PT. Asuransi Central Asia tergolong stabil dibanding perusahaan } \\
\text { asuransi lain }\end{array}$ \\
\hline
\end{tabular}
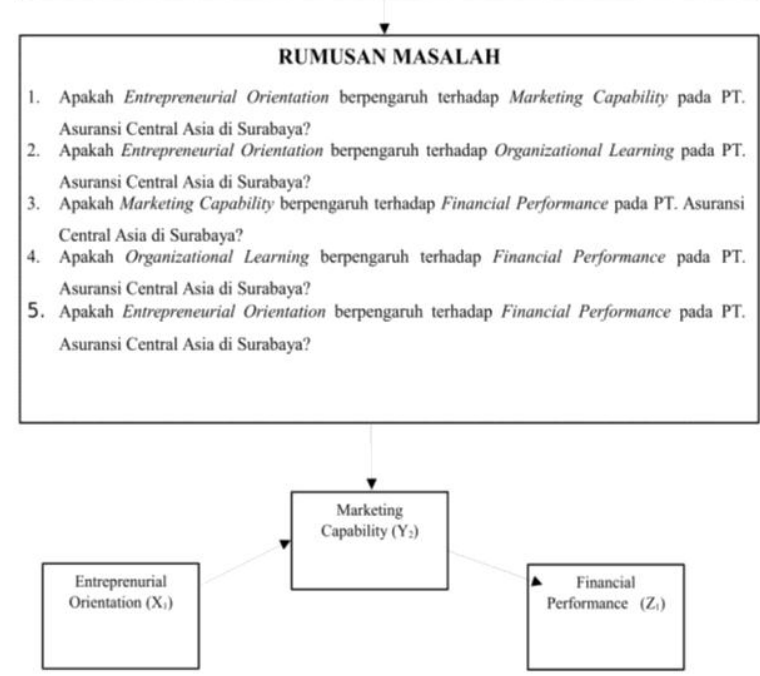

H1: Entrepenurial Orientation berpengaruh positif terhadap Marketing Capability

$\mathrm{H} 2$ : Entrepenurial Orientation berpengaruh positif terhadap Organizational Learning

H3: Entrepenurial Orientation berpengaruh positif terhadap Financial Performance

H4: Marketing Capability berpengaruh positif terhadap Financial Performance

H5: Organizational Learning berpengaruh positif terhadap Financial Performance

\section{METODELOGI PENELITIAN}

\section{Populasi dan Sampel}

Populasi merupakan seluruh data yang menjadi pusat perhatian seorang peneliti dalam ruang lingkup \& waktu yang telah ditentukan. Populasi berkaitan dengan data-data. Jika setiap manusia memberikan suatu data, maka ukuran atau banyaknya populasi akan sama dengan banyaknya manusia (Margono, 2004). Pendapat lain menyebutkan bahwa populasi adalah wilayah generalisasi yang terdiri dari obyek atau subyek yang mempunyai kualitas dan karakteristik tertentu yang diterapkan oleh peneliti untuk dipelajari dan kemudian ditarik kesimpulannya (Sugiyono, 2009). Populasi dalam penelitian ini ada- 
lah internal PT.Asuransi Central Asia, yaitu karyawan PT.ACA Surabaya.

Dalam penelitian ini, sampel diambil dengan teknik non-probability sampling, dimana semua populasi tidak memiliki peluang/kesempatan sama bagi setiap unsur atau anggota populasi untuk dipilih menjadi sampel (Sugiyono, 2001). Jenis non probability sampling yang digunakan dalam penelitian ini adalah sampling jenuh. Sampling jenuh adalah teknik penentuan sampel jika semua anggota populasi digunakan sebagai sampel (Sugiyono, 2001). Responden sebagai sampel dalam penelitian ini adalah seluruh karyawan tetap yang bekerja dalam PT. Asuransi Central Asia di Surabaya. Jumlah sampel yang digunakan adalah 65 responden, maka jumlah kuesioner akan disebarkan kepada 65 responden.

\section{Definisi Operasional Variable}

Definisi operasional variabel yang akan digunakan terdiri dari 4 variabel:

\begin{tabular}{|c|c|c|}
\hline Variabel & Dimensi & Indikator \\
\hline \multirow{5}{*}{$\begin{array}{l}\text { Entrepreneruial } \\
\text { Orientation }\end{array}$} & Innovation & $\begin{array}{l}\text { 1. Produk PT.ACA sudah menjawab kebutuhan pasar } \\
\text { 2. PT.ACA secara teratur mengeluarkan produk baru } \\
\text { 3. Adanya perluasan perlindungan (tailor made) yang ditawarkan PT.ACA } \\
\text { sehingga client merasa lebih aman dan terlindungi }\end{array}$ \\
\hline & Autonomy & $\begin{array}{l}\text { 1. Kepala cabang memiliki otoritas dalam memberikan keputusan } \\
\text { 2. Marketing memiliki otoritas dalam memutuskan penerimaan bisnis } \\
\text { 3. Kepala cabang memiliki otoritas untuk pembagian bonus }\end{array}$ \\
\hline & Risk Taking & $\begin{array}{l}\text { 1. PT.ACA berani meng-cover bisnis high risk } \\
\text { 2. Produk-produk yang dimiliki merupakan bisnis yang meng cover berbagai lini } \\
\text { yang memiliki resiko terjadi kerugian } \\
\text { 3. Adanya produk asuransi Mikro dengan resiko tinggi }\end{array}$ \\
\hline & Pro-activeness & $\begin{array}{l}\text { 1. PT.ACA melakukan expansi ke berbagai daerah untuk menjawab kebutuhan } \\
\text { akan asuransi di setiap daerah } \\
\text { 2. PT.ACA selalu mengikuti perkembangan peraturan OJK } \\
\text { 3. PT.ACA membantu OJK untuk mengembangkan produknya untuk } \\
\text { menjangkau berbagai segmentasi }\end{array}$ \\
\hline & $\begin{array}{l}\text { Competitive } \\
\text { Agresiveness }\end{array}$ & $\begin{array}{l}\text { 1. PT.ACA memberikan fasilitas lebih kepada client untuk memenangkan } \\
\text { persaingan dengan kompetitor } \\
\text { 2. PT.ACA memberikan discount lebih dibandingkan kompetitor } \\
\text { 3. PT.ACA memberikan kemudahan claim untuk para client } \\
\end{array}$ \\
\hline \multirow{3}{*}{$\begin{array}{l}\text { Marketing } \\
\text { Capability }\end{array}$} & $\begin{array}{c}\text { Marketing Sensing } \\
\text { Capability }\end{array}$ & $\begin{array}{l}\text { 1. Produk baru yang dikeluarkan sesuai kebutuhan masyarakat } \\
\text { 2. PT.ACA dapat menjawab peluang bisnis dengan cepat } \\
\text { 3. PT.ACA peka terhadap adanya ancaman atau resiko (risk management yang } \\
\text { baik) }\end{array}$ \\
\hline & $\begin{array}{l}\text { Marketing Learning } \\
\text { Capability }\end{array}$ & $\begin{array}{l}\text { 1. Fasilitas PT.ACA sudah memadai dalam menghadapi persaingan yang ada } \\
\text { 2. } \\
\text { 3. } \\
\text { PT.ACA memiliki struktur organisasi yang baik } \\
\text { PT tidak ketinggalan zaman dari segi produk maupun pelayanan }\end{array}$ \\
\hline & $\begin{array}{l}\text { Marketing } \\
\text { Targeting and } \\
\text { Positioning }\end{array}$ & $\begin{array}{l}\text { 1. PT.ACA membuat produk yang sesuai dengan target pasar yang dituju } \\
\text { 2. PT.ACA dapat menentukan apakah sebagai leader atau member insurance } \\
\text { pada suatu proyek dengan tepat } \\
\text { 3. PT.ACA mengambil share premi yang sesuai dengan kapasitas } \\
\end{array}$ \\
\hline \multirow{4}{*}{$\begin{array}{l}\text { Organizational } \\
\text { Learning }\end{array}$} & $\begin{array}{l}\text { Comitment to } \\
\text { Learning }\end{array}$ & $\begin{array}{l}\text { 1. PT.ACA sering melaksanakan evaluasi kerja di setiap divisi } \\
\text { 2. PT.ACA sering mengadakan training untuk me-refresh product knowledge } \\
\text { yang sudah ada sesuai perkembangan pasar } \\
\text { 3. Adanya kunjungan ke leasing, agent, untuk menanyakan kendala dan } \\
\text { permasalahan yang ada untuk mengoreksi kekurangan dari PT.ACA }\end{array}$ \\
\hline & Shared Vision & $\begin{array}{l}\text { 1. PT.ACA memiliki visi yang memandang jauh ke depan } \\
\text { 2. Karyawan PT.ACA bekerja sesuai dengan visi perusahaan } \\
\text { 3. PT.ACA mampu berkembang secara berkisinambungan dan diakui baik di } \\
\text { dalam negri maupun luar negri }\end{array}$ \\
\hline & $\begin{array}{l}\text { Intra-organizational } \\
\text { Knowledge Sharing }\end{array}$ & $\begin{array}{l}\text { 1. Produk PT.ACA memiliki tenaga marketing masing-masing } \\
\text { 2. Setiap marketing PT.ACA harus mengerti setiap produk yang dimiliki } \\
\text { perusahaan walaupun tidak mendalam } \\
\text { 3. Bekerja di dalam team merupakan cara yang efektif bagi PT.ACA }\end{array}$ \\
\hline & Open Mindedness & $\begin{array}{l}\text { 1. PT.ACA mampu menerima kritik membangun dari rekan maupun dari client } \\
\text { 2. PT.ACA selalu terbuka dalam penerimaan ide-ide baru dari internal maupun } \\
\text { external perusahaan } \\
\text { 3. PT.ACA menanyakan tingkat kepuasan pelanggan untuk menjaga kualitas } \\
\text { pelayanan yang dimiliki }\end{array}$ \\
\hline \multirow{4}{*}{$\begin{array}{l}\text { Financial } \\
\text { Performance }\end{array}$} & Gross Profit & $\begin{array}{l}\text { 1. Jumlah permintaan atas produk layanan asuransi yang ditawarkan PT.ACA } \\
\text { bertambah setiap tahun } \\
\text { 2. Kenaikan premi B ruto PT.ACA cukup signifikan } \\
\text { 3. Jumlah client tetap PT.ACA bertambah setiap tahun } \\
\end{array}$ \\
\hline & Net Profit & $\begin{array}{l}\text { 1. Adanya peningkatan penerimaan bonus bagi karyawan setiap tahun } \\
\text { 2. Adanya peningkatan penghasilan bagi karyawan setiap tahun } \\
\text { 3. Adanya Expansi yang dilakukan PT.ACA Surabaya dengan dibukanya cabang } \\
\text { Surabaya II }\end{array}$ \\
\hline & $\begin{array}{l}\text { Return On } \\
\text { Investment }\end{array}$ & $\begin{array}{l}\text { 1. Investasi saham Bess Insurance yang dibeli PT.ACA mampu mendukung } \\
\text { peningkatan profitabilitas perusahaan } \\
\text { 2. Investasi deposito yang dilakukan PT.ACA meningkatkan profitabilitas } \\
\text { perusahaan } \\
\text { 3. PT.ACA berinvestasi melalui anak perusahaan PT.CAR yang bergerak di } \\
\text { bidang asuransi Jiwa yang dapat meningkatkan profitabilitas PT.ACA }\end{array}$ \\
\hline & Return On Asset & $\begin{array}{l}\text { 1. Fasilitas fisik, seperti: kantor dan mobil mendukung peningkatan profitabilitas } \\
\text { PT.ACA } \\
\text { 2. Jumlah asset yang dimiliki PT.ACA membuktikan bahwa PT.ACA memiliki } \\
\text { keuangan yang kuat } \\
\text { 3. Aset tetap perusahaan seperti bangunan kantor, fasilitas kantor, dan investasi } \\
\text { berharga lainnya bertambah }\end{array}$ \\
\hline
\end{tabular}


Teknik Analisa Data

\section{Path Analysis}

Metode pengujian statistik yang akan digunakan pada model path analysis di penelitian ini adalah Partial Least Square. Partial Least Square (PLS) adalah bagian dari Structural Equation Modelling (SEM). Metode PLS ini merupakan metode baru yang sudah banyak dipakai dalam penenlitian karena dapat menggunakan jumlah sampel yang sedikit. Kelebihan dari PLS-SEM adalah metode ini mampu menyelesaikan berbagai model yang rumit/kompleks dengan berbagai variabel endogen dan variabel eksogen dengan banyaknya indikator yang ada, dapat dipakai pada sampel dengan jumlah kecil, dan dengan data distribusi yang ada (Abdillah \& Hartono, 2015).

\section{Indicator Reliability dan Internal Consistency Reliability}

Sebuah indikator dikatakan memiliki reliable yang cukup baik apabila indicatorreliability mencapai nilai $0,40-0,70$ dan dikatakan baik apabila lebih besar (>) dari 0,70. Lalu, nilai internal consistency reliability didapat dari composite reliability (Abdillah \& Hartono, 2015). Latent variabel dapat dinyatakan reliable jika nilai composite reliability lebih besar dari 0,70 .

\section{HASIL PENELITIAN DAN PEMBAHASAN}

\section{Profil Responden}

Berikut merupakan deskriptif responden dari penelitian ini, dari total 65 responden dapat diketahui bahwa:

\begin{tabular}{|c|c|c|}
\hline \multicolumn{3}{|c|}{ Jenis Kelamin } \\
\hline Jenis Kelamin & Frekuensi & Prosentase (\%) \\
\hline $\begin{array}{l}\text { Pria } \\
\end{array}$ & 39 & 60,0 \\
\hline Wanita & 26 & 40,0 \\
\hline Total & 65 & 100,0 \\
\hline \multicolumn{3}{|c|}{ Usia } \\
\hline Usia & Frekuensi & Prosentase (\%) \\
\hline $21-30$ tahun & 34 & $52,3 \%$ \\
\hline 31-40 tahun & 11 & $16,9 \%$ \\
\hline 41-50 tahun & 14 & $21,5 \%$ \\
\hline$>50$ tahun & 6 & $9,3 \%$ \\
\hline Total & 65 & 100,0 \\
\hline \multicolumn{3}{|c|}{ Divisi } \\
\hline Divisi & Frekuensi & Prosentase $(\%)$ \\
\hline Marketing & 17 & $26,2 \%$ \\
\hline Finance & 10 & $15,4 \%$ \\
\hline Accounting & 5 & $7,7 \%$ \\
\hline Collector & 5 & $7,7 \%$ \\
\hline GA & 3 & $4,6 \%$ \\
\hline Claim & 6 & $9,2 \%$ \\
\hline Underwriting & 19 & $29,2 \%$ \\
\hline Total & 65 & 100,0 \\
\hline
\end{tabular}

\section{Analisa SEM-PLS}

Indicator Reliability

\begin{tabular}{|c|c|c|c|c|}
\hline $\begin{array}{c}\text { Latent } \\
\text { Variable }\end{array}$ & Indicator & Loadings & $\begin{array}{l}\text { Indicator } \\
\text { Reliability }\end{array}$ & Kesimpulan \\
\hline \multirow{15}{*}{$\begin{array}{l}\text { Entrepreneuri } \\
\text { al Orientation }\end{array}$} & $\mathrm{X} 111$ & 0,818 & 0,669 & Cukup \\
\hline & X112 & 0,660 & 0,436 & Cukup \\
\hline & $\mathrm{X} 113$ & 0,713 & 0,508 & Cukup \\
\hline & $\mathrm{X} 121$ & 0,718 & 0,516 & Cukup \\
\hline & $\mathrm{X} 122$ & 0,687 & 0,472 & Cukup \\
\hline & $\mathrm{X} 123$ & 0,670 & 0,449 & Cukup \\
\hline & X131 & 0,699 & 0,489 & Cukup \\
\hline & X132 & 0,802 & 0,643 & Cukup \\
\hline & $\mathrm{X} 133$ & 0,811 & 0,658 & Cukup \\
\hline & X141 & 0,729 & 0,531 & Cukup \\
\hline & $\mathrm{X} 142$ & 0,838 & 0,702 & Baik \\
\hline & X143 & 0,824 & 0,679 & Cukup \\
\hline & $\mathrm{X} 151$ & 0,743 & 0,552 & Cukup \\
\hline & $\mathrm{X} 152$ & 0,825 & 0,681 & Cukup \\
\hline & $\mathrm{X} 153$ & 0,854 & 0,729 & Baik \\
\hline \multirow{9}{*}{$\begin{array}{l}\text { Marketing } \\
\text { Capability }\end{array}$} & Y111 & 0,848 & 0,719 & Baik \\
\hline & Y112 & 0,790 & 0,624 & Cukup \\
\hline & Y113 & 0,809 & 0,654 & Cukup \\
\hline & Y121 & 0,673 & 0,453 & Cukup \\
\hline & Y122 & 0,786 & 0,618 & Cukup \\
\hline & Y123 & 0,679 & 0,461 & Cukup \\
\hline & Y131 & 0,636 & 0,404 & Cukup \\
\hline & Y132 & 0,666 & 0,444 & Cukup \\
\hline & Y133 & 0,847 & 0,717 & Baik \\
\hline \multirow{18}{*}{$\begin{array}{l}\text { Organizational } \\
\text { Learning }\end{array}$} & Y211 & 0,798 & 0,637 & Cukup \\
\hline & Y212 & 0,788 & 0,621 & Cukup \\
\hline & Y213 & 0,724 & 0,524 & Cukup \\
\hline & Y221 & 0,860 & 0,740 & Baik \\
\hline & Y222 & 0,652 & 0,425 & Cukup \\
\hline & Y223 & 0,684 & 0,468 & Cukup \\
\hline & Y231 & 0,809 & 0,654 & Cukup \\
\hline & Y232 & 0,840 & 0,706 & Baik \\
\hline & Y233 & 0,808 & 0,653 & Cukup \\
\hline & Y241 & 0,765 & 0,585 & Cukup \\
\hline & Y242 & 0,832 & 0,692 & Cukup \\
\hline & Y243 & 0,812 & 0,659 & Cukup \\
\hline & $\mathrm{Z111}$ & 0,742 & 0,551 & Cukup \\
\hline & $\mathrm{Z} 111$ & 0,742 & 0,551 & Cukup \\
\hline & $\mathrm{Z} 112$ & 0,782 & 0,612 & Cukup \\
\hline & Z113 & 0,781 & 0,610 & Cukup \\
\hline & $\mathrm{Z} 121$ & 0,816 & 0,666 & Cukup \\
\hline & $\mathrm{Z} 122$ & 0,725 & 0,526 & Cukup \\
\hline \multirow{7}{*}{$\begin{array}{c}\text { Financial } \\
\text { Performance }\end{array}$} & $\mathrm{Z} 123$ & 0,909 & 0,826 & Baik \\
\hline & Z131 & 0,891 & 0,794 & Baik \\
\hline & Z132 & 0,742 & 0,551 & Cukup \\
\hline & Z133 & 0,821 & 0,674 & Cukup \\
\hline & Z141 & 0,832 & 0,692 & Cukup \\
\hline & $\mathrm{Z142}$ & 0,761 & 0,579 & Cukup \\
\hline & $\mathrm{Z143}$ & 0,819 & 0,671 & Cukup \\
\hline
\end{tabular}


Pada variabel Entrepreneurial Orientation terdapat 13 indikator yang memiliki tingkat reliabilitas yang cukup dan 2 indikator dengan tingkat reliabilitas baik. Kemudian pada variabel Marketing Capability dari total 9 indikator yang ada, 9 indikator tersebut memiliki reliabilitas yang cukup. Selanjutnya, pada variabel Organizational Learning, sebanyak 10 dari 12 indikator yang ada memiliki tingkat reliabilitas yang cukup dan 2 indikator dengan reliabilitas baik. Pada variable Financial Performance, 10 indikator memiliki tingkat reliabilitas yang cukup dan 2 indikator dengan reliabilitas baik.

\section{Stuctural Model}

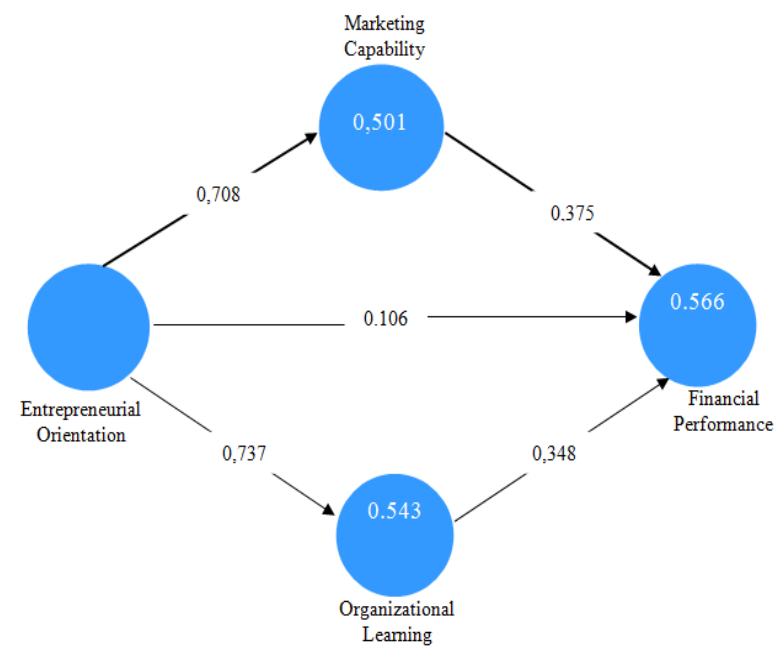

Hasil Uji Hipotesis

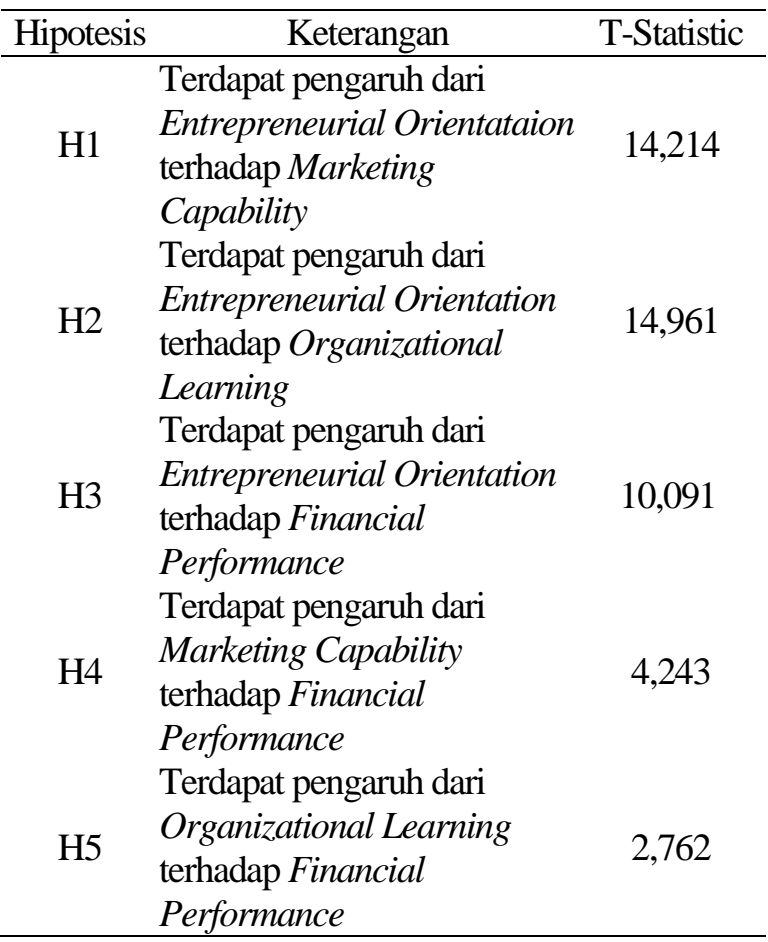

1. Pengaruh Entrepreneurial Orientation terhadap Marketing Capability memiliki nilai T-statistics 14,214, artinya terdapat pengaruh dari Entrepreneurial Orientation terhadap Marketing Capability

2. Pengaruh Entrepreneurial Orientation terhadap Organizational Learning memiliki nilai T-statistics14,961, artinya terdapat pengaruh dari Entrepreneurial Orientation terhadap Organizational Learning

3. Pengaruh Entrepreneurial Orientation terhadap Financial Performance memiliki nilai T-statistics 10,091, artinya terdapat pengaruh dari Entrepreneurial Orientation terhadap Financial Performance

4. Pengaruh Marketing Capability terhadap Financial Performance memiliki nilai $T$-statistics 4,243, artinya terdapat pengaruh dari Marketing Capability terhadap Financial Performance

5. Pengaruh Organizational Learning terhadap Financial Performance memiliki nilai T-statistics 2,762, artinya terdapat pengaruh Organizational Learning terhadap Financial Performance.

\section{Pembahasan}

\section{Entrepreneurial Orientation terhadap Marketing Capability}

Hasil penelitian ini menunjukkan bahwa variabel Entrepreneurial Orientation dari PT. Asuransi Central Asia memiliki pengaruh yang positif terhadap Marketing Capability dengan hasil nilai uji $T$ statistics> 1,96 yaitu sebesar 14,214.

Langkah PT. ACA untuk terus melakukan inovasi akan produk dan layanannya memiliki tujuan yang direncanakan oleh Perusahaan yaitu menjadi perusahaan pemimpin industri asurani umum di Indonesia. Untuk mencapai hal tersebut diperlukan adanya orientasi kewirausahaan yang bisa tercipta akibat upaya PT. ACA untuk melakukan inovasi hingga pengambilan resiko dilapangan sehingga produk PT. ACA dapat menjangkau semua segmen yang ada. Karyawan PT. ACA secara keseluruhan menilai bahwa PT. ACA telah memiliki Entrepreneurial Orientation yang baik dengan terus melakukan pengembangan produk dan layanan sehingga client merasa lebih terlindungi. Hal ini dibuktikan dengan banyaknya produk PT. ACA sehingga dibutuhkan tenaga karyawan yang tidak sedikit, kemudian PT. ACA membuat berbagai program recruitment, seperti: Profesional Insurance Program (PIP), Profesional Insurance Marketing Program (PIMP), program magang, dan lain-lain. 
Adanya orientasi kewirausahaan berujung pada kebutuhan Perusahaan untuk terus meningkatkan kemampuan pemasaran yang dimiliki, sehingga diperlukan karyawan-karyawan profesional yang mengerti betul industri asuransi, sehingga mampu menawarkan produk-produk asuransi sesuai dengan target pasar serta sesuai dengan kebutuhan konsumen yang ada melalui Marketing Capability.

Entrepreneurial Orientation sendiri memiliki nilai path positif terhadap Marketing Capability sebesar 0,708. Hal ini menunjukkan bahwaEntrepreneurial Orientation memiliki pengaruh yang kuat dalam membentuk Marketing Capability dari karyawanPT.ACA.

\section{Entrepreneurial Orientation terhadap Organizatio- nal Learning}

Pada hasil penelitian ini dapat dilihat bahwa Entrepreneurial Orientation tidak hanya memiliki pengaruh pada Marketing Capability, namun berpengaruh pula pada Organizational Learning dari PT. ACA dengan nilai uji T-statistics >1,96 yaitu1 4,961. Hasil tersebut membuktikan bahwa Entrepreneurial Orientation memiliki dampak signifikan bagi kemampuan Perusahaan untuk terus belajardan berkembang.

Entrepreneurial Orientation yang menjadi bagian utama dari PT. ACA memerlukan dukungan berupa Organisasi yang mau terus belajar dan melakukan intropeksi untuk mendukung kinerja perusahaan. Orientasi kewirausahaan yang sudah berorientasi langsung kepada perkembangan kebutuhan dan keinginan konsumen tetap membutuhkan dukungan dari organisasi yang mau terus belajar mengikuti perkembangan yang ada serta selalu melakukan intropeksi diri. Ketika PT. ACA mampu melakukan berbagai inovasi produk untuk menjawab kebutuhan konsumen, kondisi persaingan dalam industri asuransi yang terjadi tetap perlu diperhatikan dengan cara terus belajar mengikuti perkembangan zaman sehingga PT. ACA tetap dianggap sebagai perusahaan yang berkualitas dan up-to-date atau tidak ketinggalan zaman.

Sebagai dampak dari pengembangan produk dan layanan yang berkelanjutan, akan mendorong terciptanya sebuah keinginan perusahaan untuk terus belajar akan adanya perkembangan, karena dalam sebuah perusahaan tentunya tidak mungkin apabila produknya terus berkembang, namun organisasi yang bekerja memasarkan serta memroses perihal operasional tidak ikut belajar dan terus memperbaiki kekurangan yang ada. Ha ini terjadi supaya selain produk dan pelayanan yang berkembang tetapi juga organisasinya dapat berjalan secara sinergis dan menjadi perusahaan yang kuat.
Apabila melihat pada nilai path coefficient, hubungan dari Entrepreneurial Orientation menuju Organizatinal Learning memiliki nilai sebesar 0,737 yang merupakan hubungan positif.Hal ini berarti keberadaan Entrepreneurial Orientation PT. ACA mampu berperan dalam mendorong organisasi untuk terus belajar supaya mampu menjadi perusahaan yang unggul di perindustrian asuransi.

\section{Entrepreneurial Orientation terhadap Financial Performance}

Hasil penelitian ini juga menunjukkan bahwa Entrepreneurial Orientation berpengaruh cukup kuat terhadap Financial Performance. Pada hasil penelitian ini diketahui bahwa tidak adanya pengaruh kuat tersebut dari hasil uji T-statistics dengan nilai 10,091. Dikatakan cukup kuat karena T-statistics yang dimiliki lebih kecil jika di bandingkan dengan hubungan antara Entrepreneurial Orientation dengan Marketing Capability dan hubungan antara Entrepreneurial Orientation dengan Organizational Learning. Namun dari hasil penelitian ini diketahui bahwa orientasi kewirausahaan yang dimiliki PT. ACA dapat mempengaruhi performa keuangan perusahaan. Jika dilihat dari nilai path coefficient, hubungan dari Entrepreneurial Orientation menuju Financial Performance sebesar 0,106. Entrepreneurial Orientation memberikan pengaruh positif namun tidak besar dalam meningkatkan performa keuangan perusahaan.

Entrepreneurial Orientation yang dimiliki oleh PT. ACA belum mampu secara langsung dengat kuat meningkatkan performa keuangan perusahaan. Hal ini terjadi karena dalam meningkatkan performa keuangan dibutuhkan adanya kemampuan pemasaran yang baik serta organisasi yang mampu bekerja secara sinergis. Entrepreneurial Orientation saja secara langsung belum mampu untuk meningkatkan financial performance sehingga dibutuhkan adanya pengaruh dari variable intervening lainnya seperti Marketing Capability dan Organizational Learning.

\section{Marketing Capability terhadap Financial Perfor- mance}

Dalam penelitian ini dibuktikan bahwa Marketing Capability yang dimiliki oleh PT. Asuransi Central Asia akan menciptakan Financial Performance bagi perusahaan dengan nilai uji $T$-statistics $>1,96$ yaitu senilai 4,243 sehingga disimpulkan bahwa Marketing Capability berpengaruh pada peningkatan Financial Performance perusahaan.

Marketing Capability yang sudah dimiliki oleh PT. ACA membuat karyawan menjadi peka dengan 
apa yang menjadi kebutuhan konsumen, menjadi peka dalam menentukan target pasar, dan mampu memiliki produk yang up-to-date. Dengan adanya kepekaan dan adanya kemampuan pemasaran tentu saja produk-produk yang ditawarkan akan terjual sesuai dengan target. Hal ini tentunya berakibat pada meningkatnya penjualan dan penerimaan premi bruto PT. ACA. Dengan demikian, PT. ACA mampu meningkatkan performa keuangannya.

Selain itu apabila dilihat dari nilai path coefficient, hubungan dari Marketing Capability menuju Financial Performance sebesar 0,375, dimana merupakan hubungan yang baik. Nilai ini juga lebih besar jika dibandingkan dengan hubungan langsung antara Entrepreneurial Orientation dengan Financial Performance sehingga Marketing Capability terbukti berperan sebagai variabel intervening. Hal ini mengkonfirmasi bahwa kemampuan memasarkan produk berperan penting dalam meningkatkan keuangan perusahaan.

\section{Organizational Learning terhadap Financial Per- formance}

Nilai Organizational Learning terhadap Financial Performance pada PT.ACA memiliki nilai $t$ Statistic di atas 1,96 , yaitu 2,762. Nilai ini menunjukkan bahwa hubungan antara Organizational Learning dan Financial Performance memiliki nilai yang signifikan.

Organizational Learning merupakan kemampuan PT. ACA sebagai perusahaan yang mampu terus mempelajari hal-hal baru yang berhubungan dengan industri asuransi, serta terus melakukan evaluasi akan kelebihan dan kekurangannya. Hubungan ini dipersepsikan oleh karyawan sudah terjalin dengan baik. Dari adanya hubungan tersebut, karyawan akan memberikan pelayanan yang terbaik, karena sudah menerima berbagai masukan, sehingga dapat meningkatkan kepuasan kepada client yang berakibat pada bertambahnya client-client baru karena PT. ACA terkenal dengan produk dan layanannya yang unggul. Hal ini dikarenakan pembelajaran yang terjadi berulang-ulang menciptakan suatu perusahaan yang kuat sehingga memicu kualitas pelayanan yang baik, sehingga dapat meningkatkan performa keuangan perusahaan.

Nilai path coefficient dari Organizational Learning terhadap Financial Performance adalah 0,348. Nilai ini menunjukkan adanya pengaruh yang cukup kuat dari Organizational Learning terhadap Financial Performance. Karyawan PT. ACA yang memiliki rasa keterbukaan terhadap pihak internal maupun eksternal untuk menerima berbagai masukan atau kritikan yang membangun hingga terbuka dengan berbagai ide yang diberi dari client maupun sesama karyawan. Dengan demikian PT. ACA yang mampu menerima kritikan membangun akan selalu memperbaiki kekurangannya, sehingga pelayanan yang diberikan tentu maximal. Hal ini lah yang kemudian mampu mendukung peningkatan performa keuangan PT. ACA.

\section{KESIMPULAN DAN SARAN}

\section{Kesimpulan}

Hasil penelitian yang dilakukan oleh peneliti membahas mengenai pengaruh Entrepreneurial Orientation terhadap Financial Performance dengan Marketing Capability dan Organizational Learning sebagai variabel intervening, dapat disimpulkan bahwa dari seluruh pembahasan dalam penelitian ini, maka dapat disimpulkan bahwa Entreprenurial Orientation merupakan kemampuan penting yang harus dimiliki oleh PT. ACA untuk terus berkembang dan bisa menghadapi persaingan dalam industri asuransi. Hal ini dibuktikan dalam penghitungan statistik bahwa implementasi Entreprenurial Orientation berpengaruh positif terdahap Marketing Capability dan Organizational Learning serta variabelvariabel tersebut yang berperan penting dalam meningkatkan Financial Performance perusahaan.

\section{Saran}

Merujuk kepada hasil penelitian dan pembahasan, berikut ini peneliti mengajukan beberapa saran untuk PT. Asuransi Central Asia:

a. PT. ACA dapat meningkatkan penerapan Entrepreneurial Orientation. Langkah ini perting bagi perusahaan karena kemampuan perusahaan untuk terus berinovasi, berani mengambil resiko, proaktif dan agresif, karena inovasi yang dilakukan PT. ACA harus terus dikembangkan. Inovasi PT. ACA berperan penting dalam mengurangi resiko yang akan dialami client, sehingga client merasa terlindungi. Kemudian dengan adanya sikap proaktif dalam menghadapi pasar membuat produkproduk ACA tetap sesuai dengan peraturan OJK dan tentunya membantu OJK dalam mengembangkan bidang industri jasa keuangan di Indonesia.

b. Mengembangkan program training yang sudah dilakukan dengan tujuan untuk mendapatkan tenaga marketing yang handal, tidak hanya dalam product knowledge namun juga peka terhadap datangnya peluang serta tepat dalam menentukan 
target pasar sesuai dengan produknya. Selain itu dengan karyawan tetap yang tentu akan dibutuhkan training yang bertujuan untuk me-refresh kembali mengenai product knowledge yang ada, dan membutuhkan motivasi-motivasi sehingga karyawan terus memiliki semangat dalam bekerja.

c. Melakukan maintenance bagi pihak customer service secara offline di kantor melalui kuisioner atau bertanya secara lisa kepada client atau secara online melalui social media. Secara berkala perlu diadakan pengecekan atau evaluasi kembali apakah aktivitas layanan konsumen seperti penanganan keluhan dan saran sudah dilakukan dengan cepat dan tepat dengan tujuan untuk menjadi bahan intropeksi PT. ACA.

\section{DAFTAR PUSTAKA}

Abdillah, W., \& Hartono, J. (2015). Partial Least Square (PLS) - Alternatif Stuctural Equation Modeling (SEM) dalam Penelitian Bisnis (Cetakan 1). Yogyakarta: Penerbit Andy.

Argote, L. (2011). Organizational Learning Research: Past, Present and Future. Management Learning, 42(4), 439-446. http://dx. doi.org/10.1177/1350507611408217.

Calantone, R.J, Cavusgil, S.T., Zhao Y. (2002). Learning orientation, firm innovationcapability, and firm performance. Industrial Marketing Manage, 31, 515-524.

Covin, J.G., and Slevin, D.P. 1989.Strategic management of small firms in hostile and benign environments. Strategic Management Journal 10:75-87.

Crossan, M.M., Lane, H.W., \& White, R.E. (1999). An organizational learning framework: From intuition to institution. Academy of Management Review, 24(3), 522-537. http://dx.doi.org/10.5465/AMR.1999.2202135

Day, G.S. (1994). The capabilities of market driven organisations. Journal of Marketing, 58:37-51.
Hult, G.T.M., Hurley, R.F., Knight, G.A. (2004). Innovativeness: Its antecedents and impact on business performance. Industrial Marketing Management, 33, 429-438.

Lopez, S.P., Peon, J.M.M., Ordas, C.J.V. (2005). Organizational learning determining factor in business performance. The Learning Organization, 12, 227-245.

Lumpkin, G.T., and Dess, G.G. 1996. Clarifying the entrepreneurial orientation construct and linking it to performance.

Margono, Drs. S. Margono. (2004). Metodologi Penelitian Pendidikan. Jakarta: Rineka Cipta Media Asuransi. (2015, November). edisi 98, p. 18.

Miller, D. (1983). The correlates of entrepreneurship in three types of firms. Management Science, 24(9), 921-933.

Nimalathasan, B., Valeriu, B., 2010 Capitalstructure and its impact on profitability: A study of listed manufacturing companies in Sri Lanka (2010), Revista Tinerilor Economisti/The Young Economists Journal 13, 55-61.

Pratheepkanth, P. (2011). Capital Structure and Financial Performance: Evidence from Selected Business Companies. Journal of Arts, Science \& Commerce, 171-183.

Rauch, A.; Wiklund, J.; Lumpkin, G. T.; Freese, M. (2009). Entrepreneurial Orientation and Business Performance: Cumulative Empirical Evidence. Entrepreneurship Theory and Practice, vol. 33, num. 3: 761-788.

Sugiyono. 2001. Perilaku Pembelian Konsumen dan Komunikasi Pemasaran. Rosda: Bandung

Sugiyono. (2009). Metode penelitian bisnis: pendekatan kuantitatif, kualitatif, dan $R \&$ $D$ (Cetakan 14). Bandung: Alfabeta.

Ussahawanitchakit, S.S. (2015). Dynamic marketing capability and marketing survival: evidence from auto parts businesses in Thailand. The Business and Management Review, 177-188. 